\title{
Correlation of Prechtl Qualitative Assessment of General Movement Analysis with Neurological Evaluation: The Importance of Inspection in Infants
}

\author{
Prechtl Kalitatif Genel Hareket Analizinin Nörolojik Değerlendirme ile Korelasyonu: \\ Süt Çocuğu Muayenesinde İnspeksiyonun Önemi
}

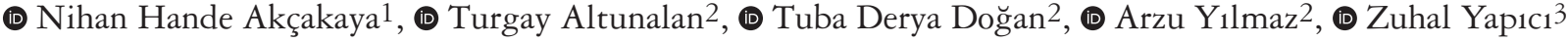 \\ ${ }^{1}$ Spastic Childrens Foundation of Turkey, Istanbul, Turkey \\ 2Spastic Childrens Foundation of Turkey, Physical and Developmental Rehabilitation Counseling, Istanbul, Turkey \\ ${ }^{3}$ Istanbul University Istanbul Faculty of Medicine, Department of Neurology, Division of Child Neurology, Istanbul, Turkey
}

\begin{abstract}
Objective: Motor development is at the forefront of evaluation of neurodevelopmental functions in the first 6 months of life. Significant spontaneous movement patterns of infants are called general movements. General movements are rough and complex movements involving the entire body. Prechtl qualitative assesment of general movements (GMA) can be performed in the first 20 weeks. It has been reported that GMA can identify motor problems with $98 \%$ sensitivity. Our aim is to investigate the specificity and sensitivity of GMA in our series by comparing the results of GMA and neurological evaluation.

Materials and Methods: Eighty infants who were less than 20 weeks old were included into the study. All infants were assessed with both neurological evaluation and video recording for the GMA at the Spastic Childrens Foundation of Turkey. As a standard technique; video recording was obtained in the GMA room of comfortably dressed infants when they were not sleepy or restless in the GMA room for 3-5 minutes in the supine position. The assessments were based on the corrected age for the preterm infants.

Results: The GMA and neurological evaluation results were found to be incompatible with each other in only 8 of 80 infants. A total of 90 video recordings were made of the 80 infants. Our study revealed that GMA can identify the motor problems with $95.8 \%$ sensitivity and $87.5 \%$ specificity.

Conclusion: Our study demonstrates that GHA may be an independent method that can identify motor problems during infancy. This study has an importance because it is one of the few independent studies that was completed by a differentiated cerebral palsy center, where GMA is applied as a standard method.
\end{abstract}

Keywords: Prechtl qualitatif assesment of general movements, neurological assessment, sensitivity, specificity, infant

$\ddot{O} \mathbf{z}$

Amaç: Hayatın ilk 6 ayında nörogelişimsel olarak değerlendirilebilen işlevlerin başında motor gelişim gelir. Bebeklerin belirgin spontan hareket paternine genel hareketler denir. Genel hareketler bütün bedeni içeren kaba ve kompleks hareketlerdir. İlk 20 haftada uygulanabilen ve bebeğin genel hareketlerini değerlendiren Prechtl kalitatif genel hareket analizinin (GHA) \%98 sensitivite ile bebekte motor problemleri yakalayabileceği bildirilmiştir. Amacımız GHA için video çekimi uygulanmış olan bebeklerin, GHA değerlendirme sonuçları ile nörolojik değerlendirmelerini karşılaştırarak GHA'nın özgüllük ve duyarlılı̆̆ını kendi olgu serimizde araştırmaktır.

Gereç ve Yöntem: Türkiye Spastik Çocuklar Vakfı'nda 20 haftasını doldurmamış GHA için video çekimi yapılmış ve nörolojik olarak değerlendirilmiş 80 bebek çalışmaya alınmıştır. Standart olarak GHA için rahat giydirilmiş uykulu ve huzursuz olmayan bebekler supin pozisyonda 3-5 dakika süre ile GHA odasında videoya alınmıştır. Değerlendirmelerde preterm bebeklerin düzeltilmiş yaşları esas alınmıştır.

Bulgular: GHA ve nörolojik değerlendirmenin sadece 8 bebekte birbiri ile uyumlu olmadığı bulunmuştur. Çalışmamızda 80 bebeğe yapılan toplam 90 çekim ile kendi serimizde GHA'nın motor gelişim problemlerini \%95,8 duyarlılık ve \%87,5 özgüllükle ortaya koyduğunu göstermektedir.

Sonuç: Çalışmamız GHA'nın standart bir yöntem olarak uygulandı̆̆ı, farklılaşmış bir serebral palsi merkezi tarafından yapılmış az sayıdaki çalışmadan biri olması açısından önem taşımakta ve GHA'nın erken bebeklik döneminde motor problemleri ortaya koyabilecek bağımsız bir yöntem olabileceğini göstermektedir. Anahtar Kelimeler: Prechtl kalitatif genel hareket analizi, nörolojik değerlendirme, duyarlılık, özgüllük, süt çocuğu

Address for Correspondence/Yazışma Adresi: Nihan Hande Akçakaya MD, Spastic Childrens Foundation of Turkey, Istanbul, Turkey Phone: +90 5335413633 E-mail: nhakcakaya@gmail.com ORCID ID: orcid.org/0000-0001-8414-4017

Received/Geliș Tarihi: 10.04.2018 Accepted/Kabul Tarihi: 24.09.2018

${ }^{\circ}$ Copyright 2019 by Turkish Neurological Society

Turkish Journal of Neurology published by Galenos Publishing House. 


\section{Introduction}

Neurodevelopmental evaluation is performed to determine whether there is a condition that decelerates, stops or regresses the development of infants and children due to any etiologic reason. Many tests have been developed for this purpose. However, the major limitation of these tests is the limited skills that can be tested in the newborn period. It has been reported that the Prechtl Qualitative Assessment of General Movements analysis (GMA) detects motor problems in the first 5 months of life with a sensitivity of $98 \%$ (1).

In the first 6 months of life, motor development is the leading skill that can be assessed in neurodevelopmental function. Any injury affecting the nervous system, such as infection, hypoxia or bleeding, or any hereditary disease may have an effect on motor development. The association of injury and hereditary disease is not uncommon in clinical practice. Regardless of the cause affecting motor development, early diagnosis, treatment, and prompt initiation of rehabilitation are important. Infants with neurodevelopmental risk factors should be monitored with regular intervals.

GMA, which is an evaluation system based on motor movements, is defined as a standardized, non-invasive, comfortable, cheap, and reliable method $(1,2)$. As a standard, GMA is the process of video recording a comfortably dressed, awake, and soothed infant for 3 to 5 minutes in the supine position (3). Recorded movements are evaluated according to the age (weeks) of the infant (3). In preterm babies, these movements should be evaluated by considering corrected age (3). The corrected age is calculated according to 40 weeks of gestation, but births between 38-42 weeks of gestation are considered term (4).

Babies have a distinct spontaneous movement pattern called (GMs) "general movements" (3). GMs are observed in fetuses as young as 9 weeks postmenstrual age (5). Normal GMs are gross and complex movements, involving the whole body. It involves the movements of the arms, legs, neck, and trunk with variable sequences and these gross movements can last several minutes or longer. The intensity, force, and speed of normal GMs show fluctuations (gradual beginning and end). In addition to the sequences of extension and flexion movements of extremities, rotations that cause slight changes in the direction of movement are also observed. These 'variable movement complexes' are fluent and elegant (6). Deterioration, attenuation, chaotic nature or disappearance and/or longer than normal for age of normal GM patterns indicate brain dysfunction $(3,6,7)$.

The aim of this study was to retrospectively investigate the GM results and neurologic evaluations of infants who underwent video recording for GMA, and to investigate the specificity and sensitivity of GMA in our case series.

\section{Materials and Methods}

\section{Participants}

The Spastic Children's Foundation of Turkey (TSCV) is a center that accepts patients from throughout Turkey for the rehabilitation of risky infants, cerebral palsy, and developmental disorders. Infants who had undergone GMA video recording, who were $<20$ weeks of gestation, and had neurologic evaluations between March 2016 and March 2018 were included in the study. The corrected ages of preterm infants were taken as a basis.

\section{GM Video Recording}

All video recordings were performed in a standard way with comfortably dressed, awake, and calm infants in the supine position while not preventing the observation of the infant's movements. The recording room is bright, at room temperature, and stimulant-free. Recording was performed with the baby alone and for a minimum of 5 minutes. During the recording, infants were monitored through an observation window, where they could not see the person who was making the recording.

\section{GM Analysis}

In order to prevent biased GMA interpretation, video analysis was performed by physiotherapists who did not perform physiotherapy to the infants and who were certified for the assessment. The GMA reporting assessment period was not longer than $45 \mathrm{~min}$ at a time and normal GMs according to age were watched in between the assessment sessions. The definition of GMs and its variability by months and pathologic conditions are explained below.

a) Definition of GMs and Pathologic Movement Patterns

The infant's known prominent spontaneous movement pattern is called GMs, as we have noted previously (3). GM patterns are diversified as primary and secondary. In infants without neurologic dysfunction, the primary GM pattern continues until about the end of the $8^{\text {th }}$ week postterm, which is then followed by a secondary pattern. The primary GM pattern is referred to as 'writhing movements' (WMs), and the secondary GM pattern is called 'fidgety movements' (FMs) (3).

The curling movements that are observed during term age and until the end of the $8^{\text {th }}$ week are referred to as WMs. They are defined as small-to-moderate amplitude, slow-to-moderate speed, and typically elliptical movements. Fast and large extensor movements may occasionally break through, particularly in the arms. There are 3 groups of movement patterns that are considered abnormal during this period: 'poor repertoire', 'cramped-synchronised', and 'chaotic' GMs. Poor repertoire describes monotonization of components of a sequence of successive movements and less complexity of movements of the different body parts as seen in normal GMs (8). Synchronised cramps are contraction and relaxation movements in the limb and trunk muscles, which are simultaneous, rigid, and lacking fluency (8). Chaotic movements are movements of all limbs with large amplitude that occur in a chaotic order without any fluency (9).

At the age of 6 to 9 weeks postterm, the character of GMs is in a spectrum ranging from WMs to FMs (10). FMs are circular movements of small amplitude and moderate speed and variable acceleration of the neck, trunk and limbs in all directions. They may be concurrent with other gross movements, such as kicking, and swiping of the arms. As long as the infant does not focus on something, they are continual in the awake infant. FMs may continue until up to 15-20 weeks postterm. The absence of FMs or abnormal FMs is considered as pathologic FMs (3). In absent FMs, FMs are never observed from ages 6 to 20 weeks postterm. In abnormal FMs, the amplitude and speed of FMs are moderately or greatly exaggerated (8). 


\section{Medical Evaluation}

A detailed medical history was taken, and physical and neurologic examination were performed as standard. Corrected age was calculated using the following formula: corrected age = postnatal age $-(40-$ gestational age $)$. The data obtained were identified according to a holistic approach.

\section{Results}

\section{Participants}

A total of 80 infants, 39 girls and 41 boys, were evaluated medically. A total of 90 recordings were made, 59 of these were aged between 9-20 weeks and 31 were aged less than 8 weeks. Ten infants were recorded both at the age of less than 8 weeks and between 9-20 weeks of age.

\section{Neurologic Findings and Diagnoses}

The diagnosis and major neurologic findings of 80 infants are presented in Table 1. The neurologic evaluations of 32 infants were found to be within normal limits in accordance with their age weeks. Thirty-one infants had pyramidal findings. Of these infants with pyramidal findings, four had only left-sided involvement, three had involvement in the lower extremities, and the others had widespread involvement. In 17 infants, the major neurologic finding was hypotonia.

Regarding the distribution of diagnoses in infants, there were no medical problems in 27 infants. Four of these infants were admitted for routine follow-up, and the remaining 23 were referred as risky infants due to premature birth. The tests could not be completed in four of the 53 infants with neurologic deficits. All of these four infants had a history of twin pregnancy and preterm birth.

In the other 49 infants with neurological deficits, 28 were found to have brain lesions due to premature birth or birth complications. All of these infants except 2 were born as preterm, one with a congenital heart anomaly and one with hypoxic ischemic encephalopathy (HIE) due to sudden death of the mother. The primary etiologies that caused neurologic deficits in 28 infants were as follows: periventricular leukomalacia (PVL) (15/28), hypoxia (12/28), intraventricular hemorrhage (IVH) (4/28), and lobar hematoma (1/28). Seventeen of the remaining 21 infants were

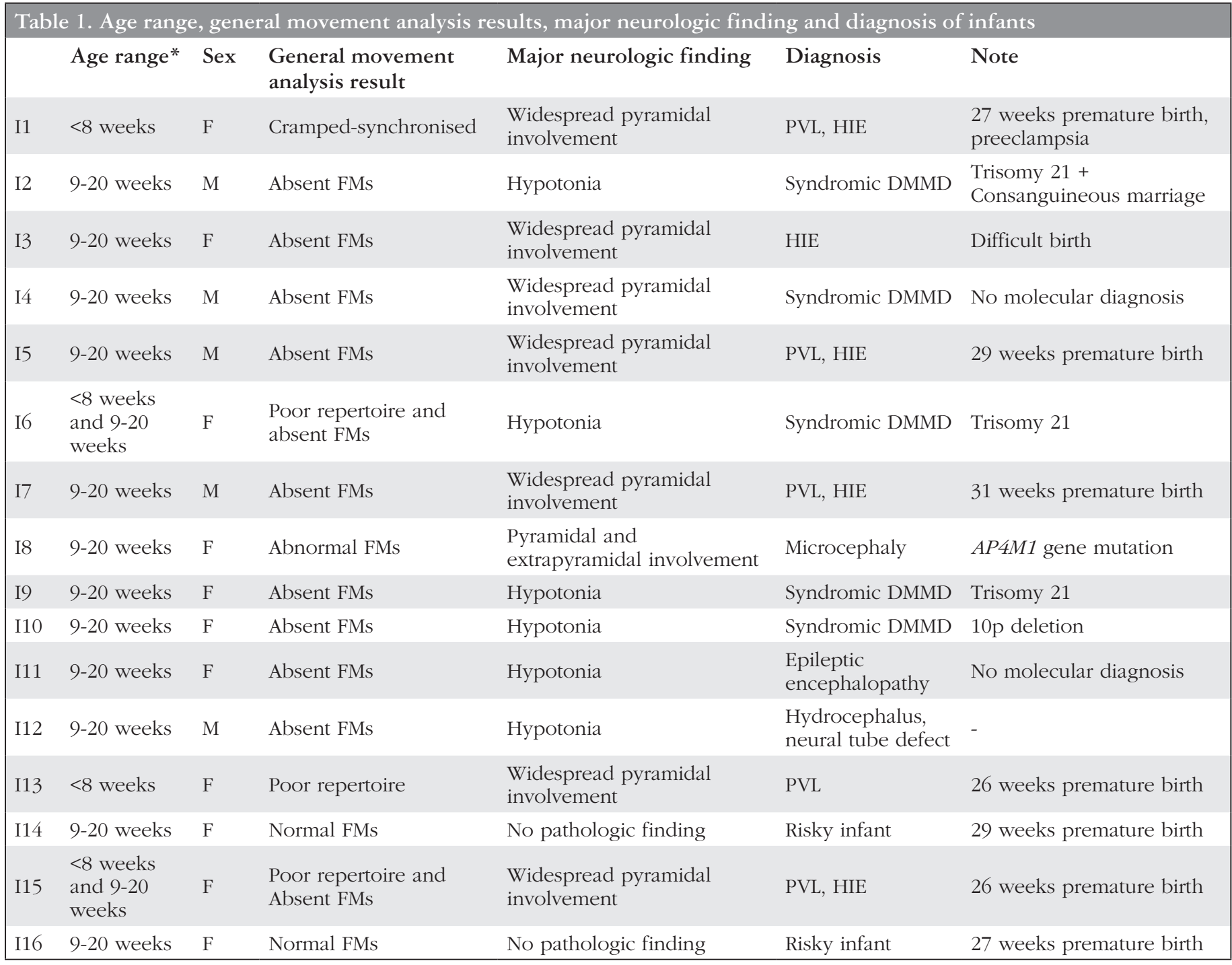




\section{Table 1. Continued}

\section{Age range* Sex General movement Major neurologic finding Diagnosis Note \\ analysis result}

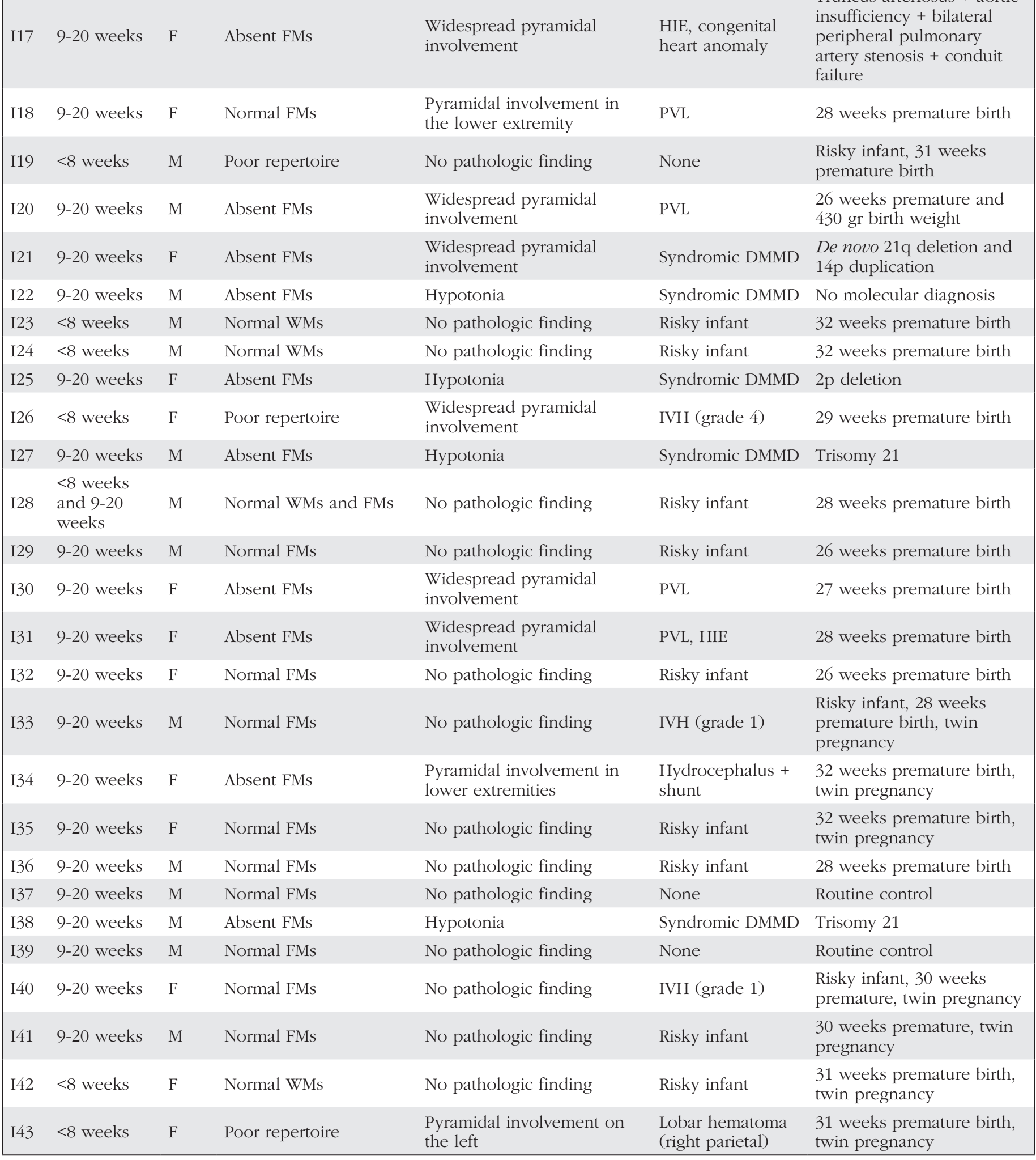


Table 1. Continued

\begin{tabular}{|c|c|c|c|c|c|c|}
\hline & Age range* & Sex & $\begin{array}{l}\text { General movement } \\
\text { analysis result }\end{array}$ & Major neurologic finding & Diagnosis & Note \\
\hline $\mathrm{I} 44$ & $\begin{array}{l}<8 \text { weeks } \\
\text { and } 9-20 \\
\text { weeks }\end{array}$ & $\mathrm{M}$ & $\begin{array}{l}\text { Poor repertoire and } \\
\text { Absent FMs }\end{array}$ & $\begin{array}{l}\text { Widespread pyramidal } \\
\text { involvement }\end{array}$ & IVH, shunt, HIE & $\begin{array}{l}34 \text { weeks premature birth, } \\
\text { twin pregnancy }\end{array}$ \\
\hline $\mathrm{I} 45$ & 9-20 weeks & $\mathrm{M}$ & Absent FMs & No pathologic finding & Risky infant & $\begin{array}{l}28 \text { weeks premature birth, } \\
\text { twin pregnancy, recording } \\
\text { in the } 9^{\text {th }} \text { week }\end{array}$ \\
\hline I46 & 9-20 weeks & $\mathrm{M}$ & Absent FMs & Hypotonia & Syndromic DMMD & Trisomy 21 \\
\hline I 47 & $<8$ weeks & $\mathrm{M}$ & Cramped-synchronised & Hypotonia & Syndromic DMMD & Trisomy 21 \\
\hline I48 & 9-20 weeks & $\mathrm{F}$ & Absent FMs & $\begin{array}{l}\text { Widespread pyramidal } \\
\text { involvement }\end{array}$ & $\begin{array}{l}\text { IVH (grade 4), } \\
\text { shunt, PVL }\end{array}$ & 26 weeks premature birth \\
\hline I49 & $\begin{array}{l}<8 \text { weeks } \\
\text { and } 9-20 \\
\text { weeks }\end{array}$ & $\mathrm{M}$ & $\begin{array}{l}\text { Poor repertoire and } \\
\text { absent FMs }\end{array}$ & $\begin{array}{l}\text { Widespread pyramidal } \\
\text { involvement }\end{array}$ & $\begin{array}{l}\text { IVH (grade 4), } \\
\text { HIE }\end{array}$ & $\begin{array}{l}30 \text { weeks premature birth, } \\
\text { uterus anomaly }\end{array}$ \\
\hline $\mathrm{I} 50$ & $<8$ weeks & $\mathrm{M}$ & Poor repertoire & $\begin{array}{l}\text { Widespread pyramidal } \\
\text { involvement }\end{array}$ & PVL & 26 weeks premature birth \\
\hline I51 & $\begin{array}{l}<8 \text { weeks } \\
\text { and } 9-20 \\
\text { weeks }\end{array}$ & $\mathrm{F}$ & $\begin{array}{l}\text { Cramped-synchronised } \\
\text { and absent FMs }\end{array}$ & $\begin{array}{l}\text { Widespread pyramidal } \\
\text { involvement }\end{array}$ & HIE & $\begin{array}{l}29 \text { weeks premature birth, } \\
\text { placental detachment }\end{array}$ \\
\hline I52 & 9-20 weeks & $\mathrm{F}$ & Absent FMs & $\begin{array}{l}\text { Widespread pyramidal } \\
\text { involvement }\end{array}$ & PVL & $\begin{array}{l}27 \text { weeks premature birth, } \\
\text { preeclampsia }\end{array}$ \\
\hline I53 & $<8$ weeks & M & Poor repertoire & Hypotonia (minimal truncal) & Syndromic DMMD & Trisomy 21 \\
\hline I54 & 9-20 weeks & M & Absent FMs & $\begin{array}{l}\text { Widespread pyramidal } \\
\text { involvement }\end{array}$ & $\begin{array}{l}\text { IVH (grade 3), } \\
\text { PVL, HIE }\end{array}$ & $\begin{array}{l}27 \text { weeks premature birth, } \\
\text { preeclampsia, resuscitation }\end{array}$ \\
\hline $\mathrm{I} 55$ & $<8$ weeks & M & Poor repertoire & No pathologic finding & IVH (grade 2) & $\begin{array}{l}25 \text { weeks premature birth, } \\
\text { twin pregnancy }\end{array}$ \\
\hline I56 & $<8$ weeks & M & Normal WMs & No pathologic finding & None & $\begin{array}{l}\text { Risky infant, } 25 \text { weeks } \\
\text { premature birth, twin } \\
\text { pregnancy, Lung bleeding } \\
\text { and PDA surgery }\end{array}$ \\
\hline $\mathrm{I} 57$ & $<8$ weeks & $\mathrm{F}$ & Normal WMs & $\begin{array}{l}\text { Pyramidal involvement in } \\
\text { the left arm }\end{array}$ & & $\begin{array}{l}34 \text { weeks premature } \\
\text { birth, twin pregnancy, } \\
\text { examination in progress }\end{array}$ \\
\hline I58 & $<8$ weeks & $\mathrm{F}$ & Poor repertoire & $\begin{array}{l}\text { Widespread pyramidal } \\
\text { involvement }\end{array}$ & & $\begin{array}{l}34 \text { weeks premature } \\
\text { birth, twin pregnancy, } \\
\text { examination in progress }\end{array}$ \\
\hline I59 & 9-20 weeks & M & Abnormal FMs & No pathologic finding & IVH (grade 1) & $\begin{array}{l}27 \text { weeks premature } \\
\text { birth, twin pregnancy and } \\
\text { preeclampsia }\end{array}$ \\
\hline 160 & 9-20 weeks & M & Normal FMs & No pathologic finding & None & Routine control \\
\hline I61 & 9-20 weeks & $\mathrm{F}$ & Normal FMs & No pathologic finding & Risky infant & $\begin{array}{l}33 \text { weeks premature birth, } \\
\text { twin pregnancy }\end{array}$ \\
\hline 162 & 9-20 weeks & $\mathrm{F}$ & Absent FMs & $\begin{array}{l}\text { Widespread pyramidal } \\
\text { involvement }\end{array}$ & & $\begin{array}{l}33 \text { weeks premature } \\
\text { birth, twin pregnancy, } \\
\text { examination in progress }\end{array}$ \\
\hline I63 & $\begin{array}{l}<8 \text { weeks } \\
\text { and } 9-20 \\
\text { weeks }\end{array}$ & M & Normal WMs and FMs & No pathologic finding & Risky infant & $\begin{array}{l}27 \text { weeks premature birth, } \\
\text { twin pregnancy }\end{array}$ \\
\hline I64 & $\begin{array}{l}<8 \text { weeks } \\
\text { and } 9-20 \\
\text { weeks }\end{array}$ & M & Normal WMs and FMs & No pathologic finding & Risky infant & $\begin{array}{l}27 \text { weeks premature birth, } \\
\text { twin pregnancy }\end{array}$ \\
\hline
\end{tabular}




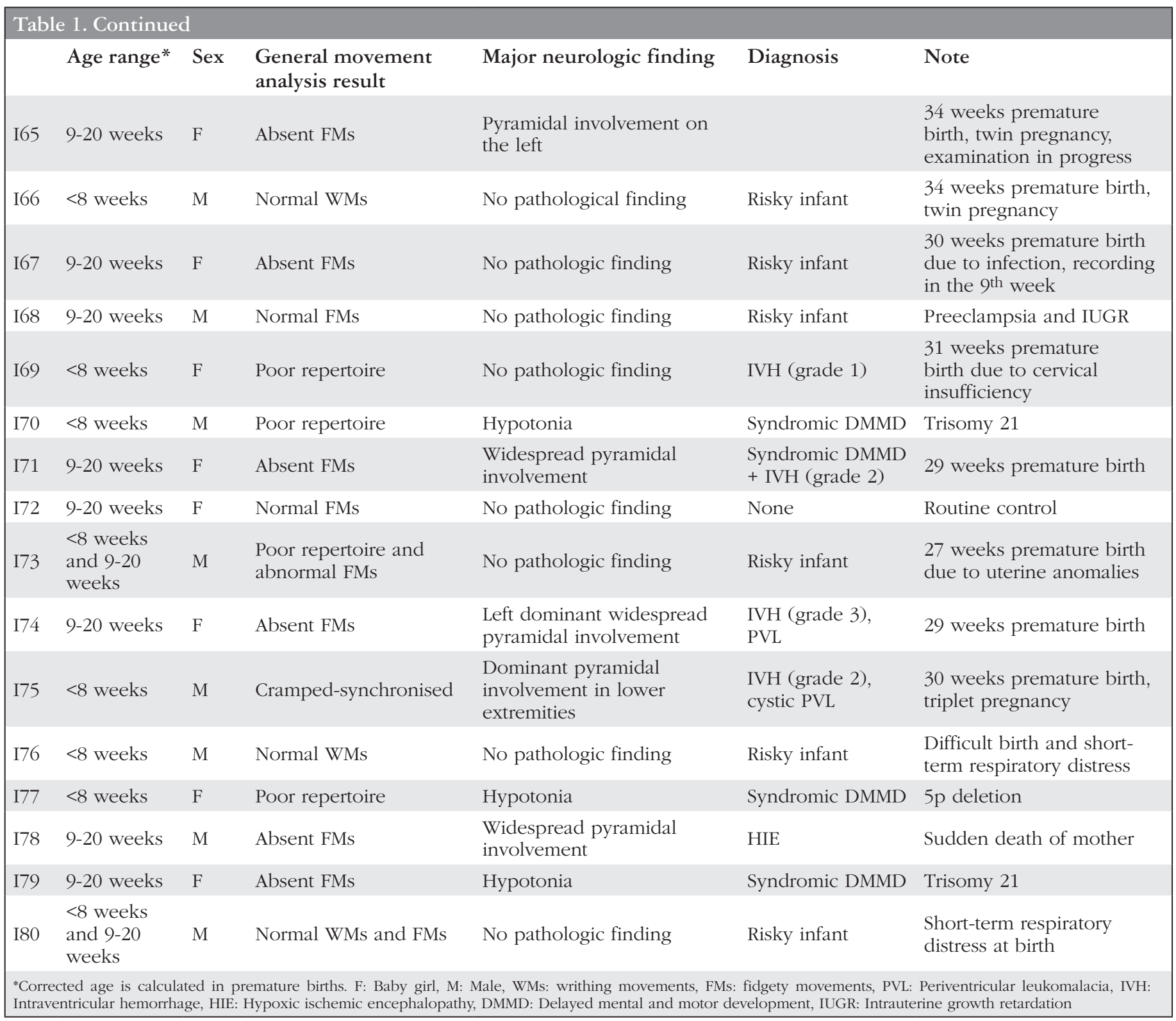

found to have syndromic mental and delayed motor development. One of the 17 infants had a history of concurrent IVH. The others had epileptic encephalopathy $(n=1)$, primary microcephaly $(n=1)$, and hydrocephalus $(n=2)$.

\section{GMs Results in Infants}

Regarding a total of 31 recordings in infants less than eight weeks of age, four infants had cramped-synchronised GMs, 16 had poor repertoire GMs, and 11 had normal WMs. The chaotic pattern was not observed in any of the infants. A total of 59 GM analyses were performed in infants aged between 9 and 20 weeks of age. There were normal FMs in 20 infants and abnormal FMs in 3 infants. Thirty-six infants had no FMs.

Five out of 10 infants who were recorded both at the age of less than 8 weeks and between 9 and 20 weeks of age had poor repertoire
GMs in the first evaluation, whereas four infants had absent FMs, and one infant had abnormal FMs in the second evaluation. One infant with cramped-synchronised GMs in the first evaluation had absent FMs in the FMs period. The remaining four infants were evaluated as having normal WMs and FMs according to their age weeks.

The GM assessments and neurologic evaluations were not compatible in 8 infants. Of these 8 infants, three were evaluated only at the age of less than 8 weeks, four were evaluated only between 9 and 20 weeks of age, and one was evaluated twice.

\section{Discussion}

To date, studies about GMA have been performed on cerebral palsy (CP), which described motor problems. It has even been 
reported that GMA is a diagnostic tool for CP (7). However, the fact that the etiology of motor involvement in infants has never been discussed is causing a limitation. In the literature, GMA is defined as a method used to make inferences about the presence of a motor deficit as well as its persistence and degree $(11,12)$. For example, data that infants with cramped-synchronised GMs in the WMs period have an increased rate of persistent motor deficits or CP development compared with those evaluated as poor repertoire GMs have been included in the literature (12). In our study, our aim was not to have a neurodevelopmental predictive approach with GMA or to investigate its relationship with CP. The aim of our study was to determine the compatibilty and reliability of GMA results with neurologic evaluations in our own patient group.

In our patient group, $46(95.8 \%)$ of 48 infants whose neurologic examinations were evaluated as pathological were found to have pathologic GM assessments. In the remaining two infants whose neurologic evaluations were incompatible with the GM results, GM results were evaluated as normal although both infants had marked tonus increase and pyramidal irritation, one in the lower extremities and one in the left arm.

Of 8 infants with incompatible neurologic evaluations and GM results, although the neurologic examinations of the remaining 6 infants were normal, the GM evaluation was pathological. Two infants had recordings during the WMs period, 3 had recordings during the FMs period, and one had recordings during both periods. The two infants in the FMs period were in corrected postterm 9 weeks in which these movements started. These two babies could not be recorded again. Twenty-eight (87.5\%) of 32 infants who were evaluated as neurologically normal had normal GMA.

The GMA has the highest neurodevelopmental sensitivity at the postterm 8-20 weeks period (11). However, it should be kept in mind that the FMs pattern could be delayed up to 9 weeks and start to disappear after 15 weeks $(3,10)$. The repetition of recordings of infants at weeks 8 and 9 may prevent false assessments of GM due to differences in the transition periods of movement patterns and may increase its reliability. Our study showed that GMA revealed motor development problems with $95.8 \%$ sensitivity and $87.5 \%$ specificity in a total of 90 recordings in 80 infants.

The FMs period has been shown to be more specific in terms of motor involvement. In a study evaluating neurologic outcomes in 130 infants, the FMs period was found to have a sensitivity of $96 \%$ and a specificity of $95 \%$ (8). In this respect, when we look back at our study, 23 of 57 babies evaluated in the FMs period were evaluated neurologically with normal limits, and four were pathological with GMA. Two of these four babies were in the $9^{\text {th }}$ week, the period of movement pattern transition from WMs to FMs. Thirty-three of 34 infants with a neurologic deficit were evaluated as pathological with GMA. In our series, the sensitivity and specificity for the FMs period of 9 weeks and above were found as $97 \%$ and $90.4 \%$, respectively. Therefore, the qualitative documentation of the assessment of FMs of infants aged 9 weeks or more is diagnostically more valuable. The medical evaluation equivalent of GMA is a systematized inspection method. Therefore, it is not surprising that GMA correlates with neurologic examinations. The high sensitivity and specificity rates emphasize the importance of inspection. The examination is only part of the medical evaluation, and the semiological approach to diagnosis should be longitudinal, not cross-sectional, in the period of infancy where the plasticity is too dense. GMA is much more valuable in predicting the diagnosis in longitudinal analyses, but it can never be used as a diagnostic tool alone. Therefore, introducing a systematized part of the examination as a diagnostic tool (7) is not semiologically appropriate and may cause medical errors. This method, depending on the practitioner and as a qualitative evaluation, can be used as a screening method to determine the presence of motor problems due to any etiologies.

Despite the neurodevelopmental predictive information about GMA in the literature $(2,7,11,12,13)$, it is important to note that the etiology, the nature, and location of the lesion in the CNS are important while conducting a neurodevelopmental study on motor involvement. Making a diagnosis of CP in a patient does not reflect a real medical diagnosis. The etiologies leading to $\mathrm{CP}$ such as placental insufficiency, preeclampsia, HIE, and IVH are true medical diagnoses. Motor involvement of these diagnoses can sometimes be predicted depending on the degree of radiologic involvement, but motor involvement may not always be seen. Again, from the etiologic point of view, the motor involvement of different diseases may be similar, while the prognosis and other accompanying findings (such as epilepsy, hearing loss, intelligence level) may be very different. No known diagnoses associated with motor problems of varying degrees according to type such as metabolic diseases, chromosomal abnormalities, epileptic encephalopathies and primary microcephaly, may not be predicted by GMA, cases should not be evaluated with a single perspective such as motor or neurological. A holistic approach is essential for the implementation of treatments in which the advantages of motor and cognitive plasticity can be optimally combined by combining all of the genetic, environmental, and individual medical properties.

From the diagnostic point of view of our study, it is seen that, out of 49 infants with neurodevelopmental problems, 28 had brain lesions and 21 had disorders primarily related to genetic factors. Twenty-six of 28 infants were preterm for various reasons. These results show that genetic factors have an important place in the etiology of neurodevelopmental problems in early infancy as well as preterm births. If there is no pregnancy complication in premature infants with neurodevelopmental problems, intrauterine and genetic problems in particuler should be considered first, and these patients should be referred to a medical genetics department.

As it can be understood from the references, this method has become widespread over the years and the publications in the scientific literature have been by the same group since 1997. Our study is important because it is one of the few studies conducted by a differentiated CP center where GMA is used as a standard method. It also shows that GMA may be an independent method for detecting motor problems in early infancy.

\section{Conclusion}

It should be noted that GMA is a cross-sectional assessment test and can only assess for risk of motor development. It can be used as a method in neurodevelopmental screening of infants because of its high correlation with neurological examination. It can be used in combination with other methods in diagnosed infants or in infants with neurodevelopmental retardation. All infants who are 
at risk should be considered medically for an early diagnosis with a holistic approach.

\section{Acknowledgements}

We would like to thank Hülya Arslan and Yasin Demirelli, the employees of the TSCV Family Counseling Center, who assisted in the recording and archiving of GMAs of infants.

\section{Ethics}

Ethics Committee Approval: The study were approved by the Spastic Childrens Foundation of Turkey (Protocol number: TSÇV.200.018.275).

Informed Consent: Consent form was filled out by all participants.

Peer-review: Externally and internally peer-reviewed.

\section{Authorship Contributions}

Surgical and Medical Practices: Z.Y., Concept: N.H.A., T.A., Design: N.H.A., Data Collection or Processing: T.A., T.D.D., A.Y., Analysis or Interpretation: N.H.A., Z.Y., Literature Search: N.H.A., T.A., Z.Y., Writing: N.H.A.

Conflict of Interest: No conflict of interest was declared by the authors.

Financial Disclosure: The authors declared that this study received no financial support.

\section{References}

1. Bosanquet M, Copeland L, Ware R, Boyd R. A systematic review of tests to predict cerebral palsy in young children. Dev Med Child Neurol 2013;55:418-426.
2. Einspieler C, Bos AF, Libertus ME, Marschik PB. The General Movement Assessment Helps Us to Identify Preterm Infants at Risk for Cognitive Dysfunction. Front Psychol 2016;7:406.

3. Einspieler C, Prechtl HF, Ferrari F, Cioni G, Bos AF. The qualitative assessment of general movements in preterm, term and young infants-review of the methodology. Early Hum Dev 1997;50:47-60.

4. Matilainen R. The value of correction for age in the assessment of prematurely born children. Early Hum Dev 1987;15:257-264.

5. de Vries JI, Visser GH, Prechtl HF. The emergence of fetal behaviour. I. Qualitative aspects. Early Hum Dev 1982;7:301-322.

6. Prechtl HFR. Qualitative changes of spontaneous movements in fetus and preterm infants are a marker of neurological dysfunction. Early Hum Dev 1990;23:151-159.

7. Einspieler C, Prechtl HF. Prechtl's assessment of general movements: a diagnostic tool for the functional assessment of the young nervous system. Ment Retard Dev Disabil Res Rev 2005;11:61-67.

8. Prechtl HFR, Einspieler C, Cioni G, et al. An early marker for neurological deficits after perinatal brain lesions. Lancet 1997;349:1361-1363.

9. Bos AF, van Loon AJ, Hadders-Algra M, et al. Spontaneous motility in preterm, small for gestational age infants. II Qualitative aspects Early Hum Dev 1997;50:131-147.

10. Prechtl HFR, Hopkins B. Developmental transformations of spontaneous movements in early infancy. Early Hum Dev 1986;4:233-238.

11. Burger M, Louw QA. The predictive validity of general movements--a systematic review. Eur J Paediatr Neurol 2009;13:408-420.

12. Ferrari F, Cioni C, Einspieler C, et al. Cramped synchronised general movements in preterm infants as an early marker for cerebral palsy. Arch Pediatr Adolesc Med 2002;156:460-467.

13. Salavati S, Einspieler C, Vagelli G, et al. The association between the early motor repertoire and language development in term children born after normal pregnancy. Early Hum Dev 2017;111:30-35. 